Teologia i Moralność, volumen 12(2017), numer 1(21)

doi: 10.14746/tim.2017.21.1.1

\author{
JANUSZ BALICKI \\ Uniwersytet Kardynała Stefana Wyszyńskiego w Warszawie \\ Wydział Nauk Historycznych i Społecznych
}

\title{
Współczesny kryzys migracyjny. Wyzwania dla Kościoła
}

\begin{abstract}
Migracje nie są czymś nowym, towarzyszyły człowiekowi od zarania dziejów, stanowiąc ważny element procesu rozwojowego każdego gatunku, w tym także homo sapiens. Biorąc pod uwagę to, że według współczesnej wiedzy kolebka ludzkości znajdowała się w Afryce, należy założyć, że to stamtąd w ciągu kilkudziesięciu tysięcy lat nasi przodkowie przemieszczali się, pokonując ogromne przestrzenie i przenosząc się na inne kontynenty w poszukiwaniu lepszych warunków życia czy też z konieczności jego utrzymania. Na zagadnienie migracji trzeba patrzeć w kontekście procesów demograficznych, które mają istotny wpływ na wędrówki jednostek i grup. Jest to zjawisko zupełnie naturalne w świecie przyrody; każdy gatunek, powiększając swą populację, szuka warunków potrzebnych do życia. W przypadku człowieka działają podobne mechanizmy, z tą różnicą, że spotyka on na swojej drodze różne regulacje prawne $\mathrm{i}$ inne bariery.

Obecnie w mocno zróżnicowanym pod względem rozwoju społeczno-ekonomicznego świecie żyje przeszło 7,4 mld ludzi. Dzisiejsze kraje rozwinięte mają za sobą intensywny przyrost naturalny XIX i początku XX wieku. Populacja Europy w 1900 roku stanowiła prawie 30\% ludności świata, obecnie to niecałe $10 \%$. Kontynent nasz znajduje się w ostatniej fazie procesu określanego terminem przejście demograficzne czy nawet już w drugim przejściu demograficznym, które charakteryzuje się brakiem zastępowalności pokoleń, starzeniem się społeczeństwa i nadwyżką zgonów nad urodzeniami. Natomiast kraje rozwijające przeżywają „,boom” populacyjny, który sprzyja migracjom. Można do tego dodać, że według prognoz w roku 2070 liczba wyznawców islamu żyjących w dużej mierze w krajach rozwijających się, czyli z wysokim przyrostem naturalnym, przewyższy liczbą chrześcijan.
\end{abstract}


Pomoże w tym trochę laicyzacja krajów rozwiniętych, ale to głównie procesy demograficzne zmniejszą proporcję chrześcijan w stosunku do muzułmanów.

Zarysowany obraz migracji komplikuje jeszcze fakt, że w ostatnich latach uaktywniły się skrajne nurty w świecie islamu, okrutniejsze od spotykanych dotąd organizacji terrorystycznych typu Al-Kaida, chodzi o tzw. Państwo Islamskie, odwołujące się do atrakcyjnej dla wielu muzułmanów idei kalifatu, czerpiące siłę z nierozwiązanych starych konfliktów (Afganistan, Irak) oraz niespełnionych nadziei „Arabskiej Wiosny”. Generuje to miliony uchodźców, z których część szuka schronienia w Europie.

Niniejszy artykuł jest próbą zwrócenia uwagi na wyzwania, jakie stawia przed Kościołem debata na temat przyjmowania imigrantów i uchodźców przybywających do Europy oraz poczucie zagrożenia bezpieczeństwa społecznego i kulturowego. Celem artykułu nie jest podawanie rozwiązań, lecz raczej ukazanie aktualnych kwestii, które nigdy dotąd od zakończenia II wojny światowej nie rodziły tylu dylematów moralnych. Ze względu na świeżość zagadnienia $\mathrm{w}$ artykule niewiele jest odniesień do literatury poświęconej ściśle teologii moralnej. Trzeba jednak wyrazić nadzieję, że refleksja teologicznomoralna nad kwestią przyjmowania uchodźców z krajów muzułmańskich w Europie w czasie kryzysu migracyjnego nie zostanie w tyle w stosunku do rozważań „świeckich”. Przykładem tego mogą być rozważania nad stosunkiem społeczeństwa polskiego do ,innych”, „obcych” podejmowane m.in. przez „Civitas” (Studia z filozofii polityki, nr 19, Gościnność, Warszawa 2016). Problemem tym zajmują się też katoliccy autorzy, niebędący teologami-moralistami, m.in. Wojciech Necel, który zwraca uwagę na niebezpieczeństwo odrzucenia obcego w potrzebie: „Przybysz zawsze jest kimś obcym, zakłóca wypracowany spokój, niepokoi, wytrąca z równowagi. W jego kontekście rodzi się pokusa na wartościowanie: dobry imigrant (bo białego koloru skóry, katolik itd.) i zły (bo innego koloru skóry, innego wyznania, obcej kultury, niezrozumiałego języka itd.)" . Obowiązkiem teologii moralnej jest korzystanie ze źródeł innych dyscyplin, które pokazują współczesne wyzwania ${ }^{2}$.

Artykuł składa się z trzech części. W pierwszej omówiony został historyczny wymiar migracji i uchodźstwa $\mathrm{w}$ świecie i Europie. Część druga prezentuje stosunek społeczeństw Europy do imigrantów i uchodźców. Część trzecia poświęcona jest obecnym migracjom i uchodźstwu jako wyzwaniom dla Kościoła.

${ }^{1}$ W. Necel, Duszpasterz ludzi $w$ drodze wobec procesu integracji kościelnej imigrantów, w: J. Balicki, M. Chamarczuk, Wokót problematyki migracyjnej. Kultura przyjęcia, Warszawa 2013, s. 276.

2 S. Olejnik, Teologia moralna fundamentalna, Włocławek 1998, s. 22-27, 33-42. 


\section{Migracje i uchodźstwo w świecie i Europie}

Aby zrozumieć współczesne migracje z krajów Afryki i Azji na nasz kontynent, należy cofnąć się do XVIII i XIX wieku, czyli do początków epoki przemysłowej w Europie. Jej owocem był m.in. rozwój medycyny, co przyniosło wydłużenie przeciętnej długości życia, a w związku z tym spadek umieralności. W tym czasie utrzymywała się ciągle wysoka dzietność i równocześnie coraz więcej dzieci dożywało dorosłego wieku. Oznaczało to praktycznie gwałtowny przyrost naturalny, którego nie był w stanie wchłonąć raczkujący przemysł ani tym bardziej małe gospodarstwa rolne, które trzeba było dzielić między liczne potomstwo. W tej sytuacji migracje na inne kontynenty były czymś zbawiennym dla Europejczyków.

Masowe wyjazdy obywateli Anglii do Ameryki rozwiązywały kwestię bezrobocia, a co za tym idzie, zapewniały państwu spokój społeczny i polityczny ${ }^{3}$. Jeśli chodzi o migracje ekonomiczne, to w latach 1846-1890 ok. $17 \mathrm{mln}$ osób opuściło Europę, wybierając się do Ameryki. Prawie 8 mln migrantów pochodziło z Wysp Brytyjskich, w tym bardzo wielu z Irlandii. Przyczyną wyjazdu z Europy tych ostatnich był głód panujący w latach 1845-1847 z powodu nieurodzaju ziemniaków. W tym samym czasie znaczna liczba ludzi wyemigrowała również z Niemiec (ok. 3,5 mln osób), także z ziem polskich, z powodu biedy panującej we wsiach i nieurodzaju zbóż. Wiele osób wyjeżdżało do USA, emigranci z Wielkiej Brytanii i Irlandii wybierali też często Kanadę, Australię, Nową Zelandię i południową Afrykę; natomiast Hiszpanie głównie Argentynę, a Portugalczycy Brazylię ${ }^{4}$. Migracje na początku XX stulecia były kontynuacją migracji z XIX wieku. Rocznie opuszczało Europę ok. 3 mln mieszkańców, co powodowało, że od połowy XIX wieku do I wojny światowej wyjechało ok. $50 \mathrm{mln}$ ludzi ${ }^{5}$.

Mówiąc o migracjach, nie można zapominać o uchodźcach opuszczających polskie ziemie w XIX wieku po nieudanych powstaniach, jak również o osobach, które musiały szukać schronienia za granicą w XX stuleciu w związku z I i II wojną światową.

Europa Zachodnia po II wojnie światowej potrzebowała imigrantów do odbudowy zniszczeń wojennych, z czego korzystali mieszkańcy byłych kolonii. Zapoczątkowało to powstawanie i rozwój mniejszości kulturowych i religijnych. Obecnie liczba migrantów w skali światowej wciąż systematycznie rośnie, w 2015 roku osiągnęła prawie $245 \mathrm{mln}$. Europa nie jest jedynym celem

3 A. Walaszek, Migracje Europejczyków 1650-1914, Kraków 2007, s. 99.

4 J. Balicki, P. Stalker, Polityka imigracyjna i azylowa. Wyzwania i dylematy, Warszawa 2006, s. 126.

${ }^{5}$ D. Stola, Wielkie migracje w Europie XX wieku, w: Cywilizacja europejska. Eseje i szkice z dziejów cywilizacji i dyplomacji, red. M. Koźmiński, Warszawa 2010, s. 356. 
migracji, są nim także inne kontynenty, w tym również bogatsze kraje Azji i Afryki ${ }^{6}$.

Niemniej jednak nasz kontynent doświadcza obecnie niespotykanej od II wojny światowej presji migracyjnej. Można wymienić kilka przyczyn tego zjawiska. Jedną z nich są podobnie jak w XIX wieku procesy demograficzne. Tym razem dotyczą one krajów rozwijających się. Jak wspomniano wyżej, demografowie badający zjawiska ludnościowe w ciągu wieków wyjaśniają je za pomocą modelu przejścia demograficznego. W uproszczeniu można powiedzieć, że trójfazowy model tego przejścia charakteryzuje się następującymi faktorami. Na początku mamy do czynienia ze społeczeństwem słabo rozwiniętym, gdzie występuje wysoka rodność, ale i wysoka umieralność, przy bardzo niskim przyroście naturalnym. W drugiej fazie spada znacząco umieralność przy wciąż dużej dzietności, co powoduje wysoki wzrost ludności. W trzeciej fazie mamy do czynienia $\mathrm{z}$ bardzo niską dzietnością i umieralnością ${ }^{7}$ Z powyższego modelu wynika, że Europę czekają ciągłe i coraz większe fale imigrantów, w tym szczególnie z krajów muzułmańskich, które obecnie przeżywają drugą fazę przejścia demograficznego. Stąd prognozy, że za 40 lat islam będzie religią z największą liczbą wyznawców na świecie.

Ważnym czynnikiem wpływającym obecnie na ruchy migracyjne jest to, że dzięki rozwiniętym technologiom ludność w ubogich państwach Azji czy Afryki ma zwykle łatwy dostęp do informacji na temat dobrobytu w Europie, co zachęca ją do podejmowania prób dotarcia na nasz kontynent, nawet z narażeniem życia. W migracjach dużą rolę odgrywają także przyczyny polityczne, jak np. sytuacja w Syrii i Libii.

W 2016 roku do Europy przybyło 388 tys. imigrantów. Jest to wyraźny spadek w porównaniu z rokiem 2015, kiedy ich liczba przekroczyła znacznie milion. Do Grecji w 2016 roku dotarło 177 tys. osób, co w porównaniu z rokiem 2015 (857 tys.) oznacza spadek o 79\%. Włochy odnotowały nieznaczny wzrost liczby przybyszów z 156 tys. w 2015 roku do 181 tys. w 2016 roku, czyli przyrost o $16 \%$. W powyższych zmianach dużą rolę odegrała umowa UE z Turcją ${ }^{8}$. Jednak w związku ze zmianami politycznymi, jakie wystąpią w tym kraju po referendum kwietniowym 2017 roku dotyczącym wprowadzenia pre-

6244 million international migrants living abroad worldwide, new UN statistics revealed, http://www.un.org/sustainabledevelopment/blog/2016/01/244-million-international-migrantsliving-abroad-worldwide-new-un-statistics-reveal [dostęp: 12.01.2016].

7 J. Balicki, E. Frątczak, Ch.B. Nam, Przemiany ludnościowe. Fakty - interpretacje - opinie. Mechanizmy przemian ludnościowych. Globalna polityka ludnościowa, Warszawa 2007, s. 204.

8 Mixed Migration Flows in the Mediterranean and Beyond, https://reliefweb.int/report/world/ mixed-migration-flows-mediterranean-and-beyond-compilation-available-data-and- 8 migration. iom.int/Europe/ [dostęp: 5.05.2017]. 
zydenckiego systemu rządów, relacje z UE mogą się znacznie popsuć, a to spowoduje brak pomocy Turcji w rozwiązywaniu kwestii imigrantów. W rozważaniach na temat migracji nie można pominąć ofiar, jakie są często składane podczas prób dotarcia do Europy. Jak podaje Raport UNHCR, w 2016 roku śmierć na Morzu Śródziemnym poniosło 5096 uchodźców i migrantów, co oznacza jeden zgon za każde 40 osób podejmujących ryzyko podróży. Około $90 \%$ z nich wybierało się do Włoch 9 .

Dotychczasowe rozwiązania stosowane w polityce migracyjnej UE sprawdzały się w przeszłości. Nie można jednak tego samego powiedzieć o obecnej sytuacji. Teraz, jak nigdy dotąd, potrzebna jest współpraca państw członkowskich. Trudno bowiem sobie wyobrazić, by państwa były w stanie indywidualnie rozwiązać obecny kryzys migracyjny ${ }^{10}$.

\section{Stosunek społeczeństw Europy do imigrantów i uchodźców}

Według badania postaw wobec cudzoziemców w Polsce, przeprowadzanego przez Ipsos dla IOM (International Organization for Migration) we wrześniu 2016 roku, procent Polaków, którzy deklarowali jakiekolwiek kontakty (spotkania) z cudzoziemcami, wynosił tylko $28 \%$. Jest to jednak znaczny wzrost z 19\% w 2015 roku. Kontakty z cudzoziemcami miały miejsce w okolicy zamieszkania (52\%) oraz w pracy (35\%). Najczęściej byli to Ukraińcy i Niemcy, a także Wietnamczycy, Rosjanie, Białorusini, Turcy, Francuzi, Włosi, Arabowie, Amerykanie, Chińczycy i Hindusi. Odsetek osób wymieniających Ukraińców stanowił ponad połowę wszystkich tych, którzy deklarowali kontakty z cudzoziemcami w Polsce.

Za najbliższych kulturowo uważani są przez Polaków mieszkańcy Europy Zachodniej (67\%), dalej Amerykanie i Kanadyjczycy (52\%) oraz Ukraińcy (51\%). Ostatnie miejsce przypada Arabom (9\%), a przed nimi Afrykanom $(13 \%)$ i Wietnamczykom $(14 \%)^{11}$. Nastawienie to przekłada się na ,sympatię" i ,zaufanie”. Społeczeństwo polskie najmniej ufa cudzoziemcom z krajów arabskich, w 2015 roku zaufanie takie wyrażało 18\%, a w 2016 roku już tylko $12 \%$. Także jedynie $14 \%$ respondentów darzy ich sympatią. Poczucie zagro-

${ }^{9}$ Refugees and migrants face heightened risks while trying to reach Europe - UNHCR report, 27 February 2017, http://www.unhcr.org/news/press/2017/2/58b458654/refugees-migrants-faceheightened-risks-trying-reach-europe-unhcr-report.html.

10 J. Balicki, Unia Europejska jako podmiot polityki wobec uchodźców, w: Uchodźcy w Europie. Uwarunkowania. Istota. Następstwa, red. A. Wojtaszczyk, J. Szymańska, Warszawa 2016, s. $110-124$.

11 Badanie na temat postaw wobec cudzoziemców w Polsce, Ipsos dla IOM, Warszawa, wrzesień 2016, http://poland.iom.int/sites/default/files/IOM_Cudzoziemcy_raport_IX_2016.pdf [dostęp: 30.10.2016.], s. 6 . 
żenia ze strony Ukraińców spadło z 35\% w 2015 roku do 30\% w 2016 roku, ale wzrosło w stosunku do Arabów do 69\%. Dla porównania w stosunku do Afrykanów wynosiło tylko $24 \%{ }^{12}$.

Prawie 2/3 badanych Polaków wyrażało obawy związane z napływem cudzoziemców do Polski. Oparte one były w dużej mierze na informacjach pochodzących z mediów oraz od innych osób. Ich poziom był najwyższy w najstarszej grupie wiekowej, powyżej 60 lat. Według badań Ipsos - 6 na 10 respondentów uważało, że cudzoziemcy stanowią zagrożenie dla kraju ${ }^{13}$.

Jeśli chodzi o opinie na temat oddziaływania cudzoziemców na kulturę w Polsce, to $23 \%$ zdecydowanie osądzało ten wpływ jako negatywny, a tylko 9\% jako pozytywny. Około 15\% Polaków znacznie przeszacowuje udział cudzoziemców w populacji mieszkańców Polski, podając, że przekracza on 10\% ${ }^{14}$.

Niechęć do Arabów wiąże się $\mathrm{z}$ awersją do muzułmanów, która wynika $\mathrm{z}$ łączenia ich $\mathrm{z}$ terroryzmem, ale także $\mathrm{z}$ negatywnych stereotypów dotyczących ich pracowitości czy uczciwości.

W Polsce $(38,5$ mln mieszkańców) liczba muzułmanów w porównaniu z krajami zachodniej Europy jest bardzo mała (ok. 30 tys.). Pod koniec 2016 roku Niemcy miały 82,8 mln mieszkańców. Jest to rekord, który zawdzięczają imigrantom, w tym muzułmanom, których dokłada liczba obecnie jest trudna do ustalenia. Pew Reaserch Center podawał w 2016 roku, że już w 2010 roku muzułmanie w Niemczech przekraczali $4,8 \mathrm{mln}$, co stanowiło 5,8\% mieszkańców, na drugim miejscu była Francja $(63,9 \mathrm{mln})$ - 4,7 mln muzułmanów - 7,5\% ludności, na trzecim Wielka Brytania $(64,1 \mathrm{mln})$ - 2,96 mln muzułmanów - 4,8\% ludności. W pozostałych krajach Europy jest już znacznie mniej wyznawców islamu: we Włoszech - 2,2 mln, w Holandii i Hiszpanii po około $1 \mathrm{mln}^{15}$. Od tego czasu wiele się zmieniło, zważywszy, że do samych Niemiec w 2015 roku i 2016 roku przybyło razem znacznie ponad milion imigrantów ${ }^{16}$, z których większość pochodziła z krajów muzułmańskich.

Można zauważyć pewną prawidłowość dotyczącą nastawienia do muzułmanów, im mniej ich w danym kraju, tym większa do nich wrogość (wykres 1). W Wielkiej Brytanii 28\% społeczeństwa jest nastawiona do muzułmanów negatywnie. Niewiele więcej w Niemczech i Francji. Najwyższy poziom niechęci występuje na Węgrzech (72\%), we Włoszech (69\%) i Polsce (66\%). O ile w przypadku Węgier i Włoch stosunek ten można próbować wyjaśniać

12 Tamże, s. 7.

13 Tamże, s. 8.

14 Tamże, s. 12.

155 facts about the Muslim population in Europe, Pew Research Center 19.07.2016 [dostęp: 30.07.2016].

${ }^{16}$ B. Dudek, DW, http://www.dw.com/pl/niemcy-rekordowy-przyrost-ludno\%C5\%9Bci/a-3730 8973 [dostęp: 30.09.2017]. 
obawą przed napływającymi wciąż imigrantami, to nie dotyczy to na pewno Polski.

\section{Wykres 1.}

\section{Negatywne nastawienie do muzułmanów w wybranych krajach Europy}

Źródło: Pew Reaserch Center 19.07.2016.

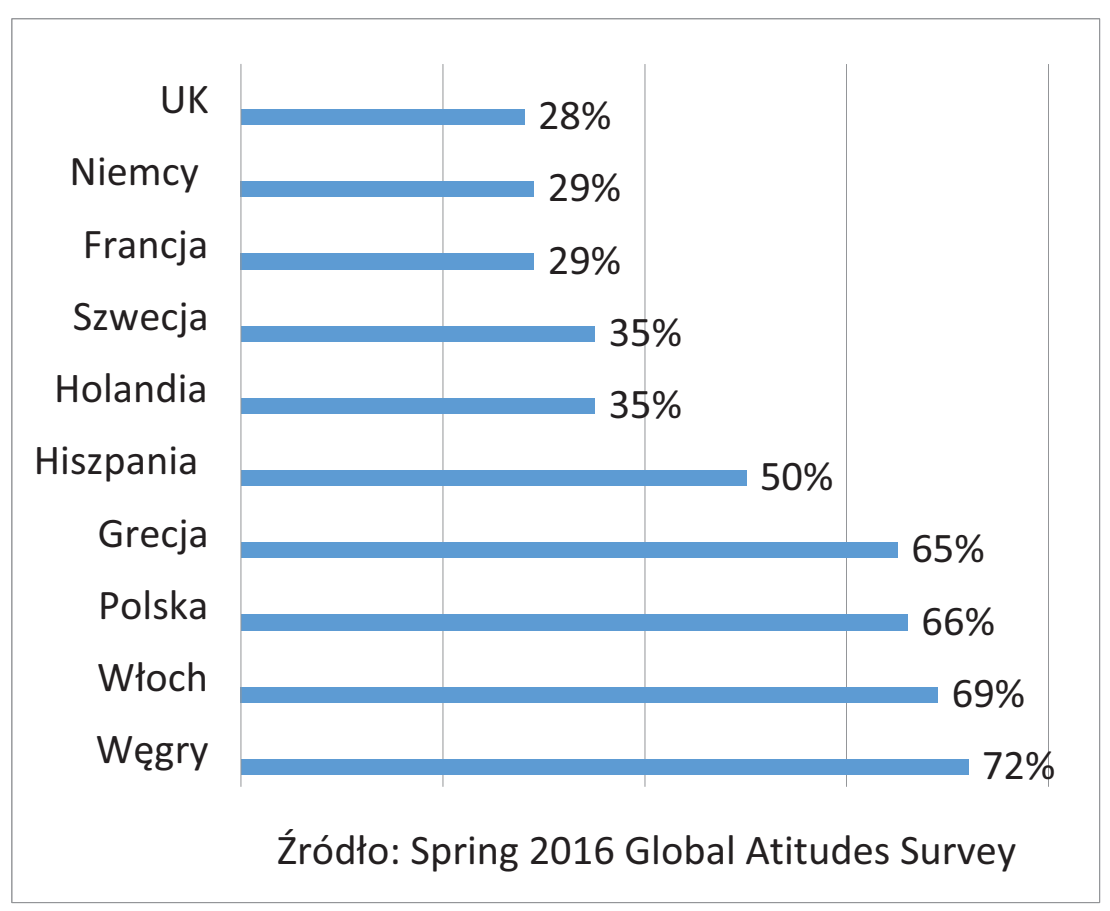

W Polsce mamy niewielkie wspólnoty muzułmańskie, które trudno dokładnie oszacować. Według Narodowego Spisu Powszechnego w 2011 roku przynależność do Muzułmańskiego Związku Religijnego w RP zadeklarowało 2585 osób, do Islamskiego Zgromadzenia Ahl-ul-Bayt 1276 osób, a do Ligi Muzułmańskiej 732 osoby ${ }^{17}$. Nie jest to jednak pełna liczba, zwykle przyjmuje się, że wyznawcy islamu stanowią około $0,1 \%$ wszystkich mieszkańców naszego kraju, czyli przeszło 30 tys. Natomiast społeczeństwo polskie jest przekonane, że mieszka ich u nas kilka milionów. Polacy pytani przez Instytut badawczy Ipsos MORI uważali, że muzułmanie stanowią 7\% populacji kraju, czyli 2,6 mln, a do 2020 roku ich odsetek wzrośnie do 13\% ludności kraju, czyli do $5 \mathrm{mln}^{18}$. Z badań CBOS z 2015 roku wynika, że zaledwie 12\% Pola-

17 Wyznania religijne w Polsce, GUS, Warszawa 2016, s. 142-148.

${ }_{18}$ M. Wojtalik, Ilu muzułmanów mieszka w Polsce? Polacy bardzo się myla, Newsweek.pl, 14.12.2016, http://www.newsweek.pl/polska/ilu-muzulmanow-mieszka-w-polsce-dane-i-wyniki-ba dan,artykuly,402066,1.html/ [dostęp: 15.12.2016]. 
ków poznało osobiście jakiegoś muzułmanina i najprawdopodobniej nastąpiło to za granicą ${ }^{19}$. Mimo to $\mathrm{w}$ polskim społeczeństwie istnieje silne przekonanie o zagrożeniu kulturowym związanym z szybkim przyrostem naturalnym w społecznościach muzułmańskich w Europie. Chociaż w latach 2005-2010 współczynnik dzietności był rzeczywiście wyższy w rodzinach muzułmańskich $(2,2$ do 1,5$)$ i przewiduje się, że będzie w dalszym ciągu wyższy w latach 2025-2030 (2,0 do 1,6), to jednak nie jest to różnica usprawiedliwiająca poczucie istniejącego obecnie zagrożenia czy wręcz islamofobii ${ }^{20}$.

Sławomir Łodziński twierdzi, że nastawienie polskiego społeczeństwa do imigrantów przybrało cechy zjawiska ,medialnej paniki moralnej”. Jest to pojęcie funkcjonujące w polskiej literaturze. Charakteryzuje się ono poczuciem dysproporcji poziomu lęku do rzeczywistego znaczenia tego zjawiska. Związana jest z tym stereotypizacja i stygmatyzacja danej kategorii społecznej. Udział mediów w informowaniu na temat rozwoju tego zjawiska powoduje, że ich odbiorcy stają się z czasem coraz bardziej przekonani, iż poruszany problem jest nie tylko rzeczywisty, ale może ich nawet osobiście dotykać, co oznacza także wzrost ,publicznej nerwowości”. Media mogą zamiast zmniejszać poziom lęku społecznego, wprost przeciwnie - wzmacniać go ${ }^{21}$.

Przytoczone wyżej fakty wyjaśniają w jakiejś mierze negatywny stosunek do muzułmanów w Polsce oraz wskazują na potrzebę zajęcia się tym zagadnieniem. Centrum Edukacji o Uchodźcach w Warszawie wyszło naprzeciw nauczycielom, którzy podejmują wysiłek prowadzenia tego tematu w szkołach. Dominika Cieślikowska w komentarzu do scenariuszy lekcji: „Jak rozmawiać o uchodźcach" - zwraca uwagę na trudności, jakie może spotkać nauczyciel. Jej zdaniem:

[...] liczne nieścisłości, a nawet przekłamania odnośnie zjawiska migracji i uchodźstwa (w tym nieumiejętne odróżnianie faktów od opinii) spowodowały u wielu ludzi nie tylko obojętność czy dezorientację, ale i lęk, niechęć, czy w niektórych przypadkach wręcz nienawiść prowadzącą do agresji, zarówno w postaci ataków werbalnych, jak i - w skrajnych przypadkach - fizycznych - wobec migrantów i uchodźców ${ }^{22}$.

19 Tamże.

20 J. Balicki, Przesłanki demograficzne islamofobii w Zachodniej Europie. Analiza krytyczna, „Roczniki Nauk Społecznych KUL” t. 6, nr 3, 2014, s. 11-30.

21 S. Łodziński, Migracyjna „panika moralna”? Polska opinia publiczna wobec udzielania pomocy uchodźcom w okresie maj - grudzień 2015 r., w: Kryzys migracyjny w Europie. Wyzwania etyczne, społeczno-kulturowe i etniczne, red. J. Balicki, W. Necel, Warszawa 2017, s. 157.

22 D. Cieślikowska, Jak rozmawiać o uchodźcach - komentarz do scenariuszy lekcji, w: Rozmowy o uchodźcach, Centrum Edukacji Obywatelskiej. Centrum edukacji o uchodźcach, https:// migracje.ceo.org.pl/materialy-metodyczne/ [dostęp: 1.06.2017]. 
Wobec tego podjęcie w szkołach tematu dotyczącego imigrantów i uchodźców jest niezwykle potrzebne. Nie wszyscy nauczyciele są przygotowani do prowadzenia takich zajęć. Problematyka ta bowiem wzbudza wiele emocji. W polskim społeczeństwie poziom wiedzy na temat uchodźców jest bardzo niski. Polska jest krajem emigracji.

Statystyczny Polak nie miał zatem zbyt wielu okazji do spotkania uchodźcy czy uchodźczyni osobiście, niewiele się o nich dowiedział w trakcie edukacji czy z mediów, bowiem cały system polityczno-społeczny nie sprzyja ani rzetelnemu podejmowaniu tematu, ani poznawaniu ludzi, których bezpośrednio dotyczy. [...] Wprowadzając wiele nieprzemyślanych i mało trafnych przekazów o uchodźcach, zwiększył dysproporcję pomiędzy faktami a mitami na rzecz tych drugich ${ }^{23}$.

W świetle tych opinii nasuwa się pytanie: Czy katecheci są przygotowani do podejmowania tematu uchodźców i czy je podejmują? Dokument Chrześcijański ksztalt patriotyzmu wydany na początku 2017 roku przez Konferencję Episkopatu Polski zwraca uwagę na rolę, jaką odgrywają nauczyciele i wychowawcy w kształtowaniu prawidłowego stosunku do osób innej narodowości ${ }^{24}$.

Jak wynika z wykresu 1, niemieckie społeczeństwo jest znacznie bardziej otwarte na imigrantów niż polskie. Jak podaje Bernadette Jonda, w roku 2015 Kościół katolicki w Niemczech przeznaczył prawie $100 \mathrm{mln}$ euro na pomoc dla uchodźców. Diecezje, dzieła pomocy, stowarzyszenia katolickie, zakony i wspólnoty wspierają uchodźców na miejscu nie tylko finansowo, ale też przez bezpłatne udostępnienie co najmniej 800 budynków noclegowych i obiektów mieszkalnych, zatrudniając ponad 3000 pracowników. W pomoc dla uchodźców zaangażowanych jest też co najmniej 100 tys. woluntariuszy ${ }^{25}$.

\section{Migracje i uchodźstwo jako wyzwania dla Kościoła}

Wojciech Necel zaznacza, że kilka lat przed początkiem kryzysu migracyjnego Benedykt XVI w Encyklice Caritas in veritate powiedział, że świat współczesny stoi

23 Tamże.

${ }^{24}$ Chrześcijański ksztalt patriotyzmu. Dokument Konferencji Episkopatu Polski przygotowany przez Radę ds. Społecznych, 27.04.2017, http://episkopat.pl/chrzescijanski-ksztalt-patriotyzmudokument-konferencji-episkopatu-polski-przygotowany-przez-rade-ds-spolecznych/ [dostęp: 30.04. 2017].

${ }_{25}$ B. Jonda, Muzułmańscy imigranci i uchodźcy ,papierkiem lakmusowym” dla niemieckiego społeczeństwa?, w: Kryzys migracyjny w Europie, dz. cyt., s. 181. 
wobec zjawiska społecznego o charakterze epokowym, wymagającego silnej i dalekosiężnej polityki współpracy międzynarodowej, by można mu było odpowiednio stawić czoło. Taką politykę należy rozwijać zaczynając od ścisłej współpracy między krajami, z których pochodzą emigranci, a krajami, do których przybywają. Powinny jej towarzyszyć stosowne rozporządzenia międzynarodowe, zdolne zharmonizować różne porządki legislacyjne tak, by zabezpieczyć potrzeby i prawa osób oraz rodzin emigrantów, a jednocześnie społeczeństwa, do którego dotarli. Żaden kraj nie może uważać, że sam podoła problemom migracyjnym naszych czasów. Wszyscy dostrzegamy ciężar cierpienia, przykrości i aspiracji, towarzyszący ruchom migracyjnym $(160)^{26}$.

Papież Franciszek kontynuuje to nauczanie. W Orędziu na Światowy Dzień Migranta i Uchodźcy: Migranci i uchodźcy sa dla nas wyzwaniem. Odpowiedź daje Ewangelia miłosierdzia - z 17 stycznia 2016 roku przypominał, że jesteśmy odpowiedzialni także za ludzi, którzy starają się dotrzeć do Europy nawet z pobudek materialnych, dlatego że są naszymi braćmi i siostrami:

[...] każdy z nas jest odpowiedzialny za swojego bliźniego: jesteśmy stróżami naszych braci i sióstr, niezależnie gdzie żyją. Troska o dobre relacje osobiste i zdolność do przezwyciężenia uprzedzeń i lęków są istotnymi czynnikami w pielęgnowaniu kultury spotkania, gdzie jest się gotowym nie tylko dawać, ale również przyjmować od innych. Gościnność bowiem polega na dawaniu i przyjmowaniu ${ }^{27}$.

Papież nazywa imigrantów wprost naszymi braćmi i siostrami, którzy poszukują „lepszego życia, z dala od ubóstwa, głodu, wyzysku i niesłusznego podziału zasobów naszej planety, które powinny być rozdzielone równo między wszystkich ludzi"28. Zastanawiające jest, że ten element jest zwykle pomijany lub wykorzystywany do usprawiedliwienia zamykania granic państw przed nimi. Ojciec Święty przypomina naukę społeczną Kościoła dotyczącą niesprawiedliwości społecznej i nierównego podziału dóbr. Oczywiście można powiedzieć, że osób, które potrzebowałyby takiej pomocy, jest dużo więcej na świecie niż mieszkańców bogatej Europy, ale z drugiej strony obowiązek pomocy istnieje najpierw wobec tych, którym możemy pomóc. Imigranci są takimi ludźmi.

${ }^{26}$ W. Necel, Kultura przyjęcia wobec imigrantów wg instrukcji Erga migrantes caritas Christi, w: Kryzys migracyjny w Europie, dz. cyt., s. 83.

27 Orędzie Franciszka na Światowy Dzień migranta i uchodźcy 2016, „, Migranci i uchodźcy sa dla nas wyzwaniem. Odpowiedź daje Ewangelia miłosierdzia”, 17 stycznia 2016, https://stacja7. $\mathrm{pl} / \mathrm{z}$-watykanu/oredzie-franciszka-na-swiatowy-dzien-migranta-i-uchodzcy [dostęp: 1.03.2016].

28 Tamże. 
Następnie papież przechodzi do argumentacji moralnej, zwracając uwagę, że

[...] każdego dnia dramatyczne historie milionów mężczyzn i kobiet są wyzwaniem dla Wspólnoty Międzynarodowej w obliczu pojawiających się w wielu regionach świata niedopuszczalnych kryzysów humanitarnych. Obojętność i milczenie otwierają drogę do współodpowiedzialności, zwłaszcza gdy przyglądamy się biernie, jak ludzie giną przez uduszenie, $\mathrm{z}$ głodu, na skutek przemocy i katastrof na morzu. Zawsze są to tragedie, o mniejszych lub większych rozmiarach, kiedy ginie choćby jedno życie ludzkie ${ }^{29}$.

W dalszej argumentacji Ojciec Święty odwołuje się do Pisma Świętego, gdzie można znaleźć teksty mówiące, że przyjmując obcokrajowca, otwiera się drzwi Bogu. Argumenty te konfrontuje z postulatami ograniczenia gościnności nie tylko w wypowiedziach polityków, ale także w niektórych wspólnotach parafialnych, które widzą zagrożenie dla tradycyjnego spokoju. Zadaje więc retoryczne pytanie: Czy Kościół może działać inaczej, niż wzorując się na przykładzie i słowach Jezusa Chrystusa?

W takiej perspektywie, zdaniem papieża, ważne jest patrzenie na migrantów nie tylko z punktu widzenia ich uregulowanego lub nieuregulowanego statusu. Nie można ograniczać migracji tylko do wymiarów politycznych i prawnych, do konsekwencji ekonomicznych i czystego współistnienia różnych kultur na tym samym terytorium. Zgadza się on, że obecność migrantów i uchodźców staje się poważnym wyzwaniem dla wielu społeczeństw, które ich przyjmują. Mogą oni kwestionować ich tradycyjny sposób życia, a niekiedy „,naruszają horyzont kulturowy i społeczny”30, z którym się stykają. Niemniej jednak ostatecznie papież stwierdza: „przyjęcie bliźniego to przyjęcie samego Boga!"31.

Przy zastosowaniu istniejącego $\mathrm{w}$ dyskursie społecznym podziału na „religijną” prawicę i „niereligijną” lewicę widać pewien paradoks. Należałoby oczekiwać, że „religijna” prawica będzie naturalnym sojusznikiem Ojca Świętego. Jest jednak odwrotnie, to ,niereligijna” lewica podejmuje działania na rzecz imigrantów i uchodźców, które są znacznie bliższe etosowi ewangelicznemu niż poglądy „religijnej” prawicy. Jako przykład można przytoczyć stanowisko Julia Loreda zaprezentowane w artykule we włoskim miesięczniku „Radici Cristiane” publikowanym w Polsce pod koniec października 2016 roku. Wbrew stanowisku papieża traktuje on imigrację z krajów muzułmańskich jako „zaplanowany najazd na Europę”, z góry zakładając, że nie mogą

29 Tamże.

30 Tamże.

31 Tamże. 
się integrować z żadną kulturą, a szczególnie z kulturą chrześcijańską. Podważa liczne wypowiedzi czy gesty papieża Franciszka (nie wymieniając go po imieniu), kwestionując obowiązek gościnności: „niektórzy ludzie, zwłaszcza w kręgach katolickich, mówią o obowiązku gościnności" 32 . Jego zdaniem, nakaz gościnności nie dotyczy uchodźców z krajów muzułmańskich bo: „Tak jak rodzina nie ma moralnego obowiązku przyjąć w swoim domu niechcianych gości, którzy mogliby zniszczyć życie rodzinne, tak i państwo - albo nawet kontynent - nie ma moralnego obowiązku akceptowania imigracji, która zniszczy tkankę społeczną, a zwłaszcza - co jeszcze ważniejsze - wiarę" ${ }^{33}$.

Takie stanowisko popularne zwłaszcza w Europie Środkowo-Wschodniej (wykres 1) podważa Sobór Watykański II, który w Deklaracji o stosunku Kościoła do religii niechrześcijańskich (dalej: DRN) wypowiada się z szacunkiem na temat różnych religii, w tym także islamu:

Kościół spogląda z szacunkiem również na muzułmanów oddających cześć jedynemu Bogu, żywemu i samoistnemu, miłosiernemu i wszechmocnemu, Stwórcy nieba i ziemi, Temu, który przemówił do ludzi; Jego nawet zakrytym postanowieniom całym sercem usiłują się podporządkować, tak jak podporządkował się Bogu Abraham, do którego wiara islamu chętnie nawiązuje. Jezusowi, którego nie uznają wprawdzie za Boga, oddają cześć jako prorokowi i czczą dziewiczą Jego Matkę Maryję, a nieraz pobożnie Ją nawet wzywają. Ponadto oczekują dnia sądu, w którym Bóg będzie wymierzał sprawiedliwość wszystkim ludziom wskrzeszonym z martwych. $Z$ tego powodu cenią życie moralne i oddają Bogu cześć głównie przez modlitwę, jałmużny i post ${ }^{34}$.

Autorzy Deklaracji mają wprawdzie świadomość trudności w relacjach chrześcijańsko-muzułmańskich w historii, ale zachęcają aby: ,„...] wymazując z pamięci przeszłość szczerze pracowali nad zrozumieniem wzajemnym i w interesie całej ludzkości wspólnie strzegli i rozwijali sprawiedliwość społeczną, dobra moralne oraz pokój i wolność" 35 .

Na wypowiedzi Ojca Świętego na temat imigrantów i uchodźców oparte na nauce Soboru Watykańskiego II różnie reagują członkowie Kościoła. Przywołany poniżej komentarz wprawdzie nie wyszedł spod pióra żadnego znanego polskiego autora, został umieszczony anonimowo w Internecie, niemniej jednak, jak się wydaje, reprezentuje dość rozpowszechniony sposób myślenia:

32 J. Loredo, Imigracja czy inwazja? „Nasz Dziennik” 24 października 2016 (przedruk z włoskiego miesięcznika „Radici Cristiane”, tłum. P. Jaroszyński, http://www.naszdziennik.pl/ mys1/168935,imigracja-czy-inwazja.html [dostęp: 6.12.2016].

33 Tamże.

${ }^{34}$ Sobór Watykański II, Deklaracja o stosunku Kościoła do religii niechrześcijańskich Nostra aetate, w: Sobór Watykański II, Konstytucje. Dekrety. Deklaracje, Poznań 1968, s. 335.

35 Tamże, s. 336. 
Już nie pierwszy raz papież Franciszek powołuje się na słowa (Mt 25,35), które przy największej chęci nie da się przypisać sprawom uchodźców. Dlatego aby raz na zawsze rozwiać te wątpliwości wklejam przywołane słowa: Wówczas zapytają sprawiedliwi: „Panie, kiedy widzieliśmy Cię głodnym i nakarmiliśmy Ciebie? spragnionym i daliśmy Ci pić? Kiedy widzieliśmy Cię przybyszem i przyjęliśmy Cię? lub nagim i przyodzialiśmy Cię? Kiedy widzieliśmy Cię chorym lub w więzieniu i przyszliśmy do Ciebie?” A Król im odpowie: „Zaprawdę, powiadam wam: Wszystko, co uczyniliście jednemu z tych braci moich najmniejszych, Mniecie uczynili". (Mt 37-40).

Od kiedy to islam jest bratem Pana Jezusa Chrystusa??? A kto jest bratem (najmniejszym) Pana Jezusa Chrystusa? No ten ponad wszelką watpliwość, co w Niego uwierzył i uznał GO ZA SWOJEGO PANA.

Zatem nadużywanie tych słów przez papieża Franciszka zwiastuje coś złego. To nie jest normalne. Papież za wszelką cenę chyba chce islamizować Europę, bo jego wypowiedź cyt: „Wybaczcie zamknięcie i obojętność naszych społeczeństw, które obawiają się zmiany życia i mentalności, jakiej domaga się wasza obecność,” znaczy nic więcej jak: „Wybaczcie zamknięcie i obojętność naszych społeczeństw, które obawiają się zamiany katolicyzmu na islam, obawiają się gwaltów i nieludzkich morderstw przez ucinanie głów (podobne), ale nie martwcie się ja ich do tego przyzwyczaję". Króluj nam Panie Jezu Chryste ${ }^{36}$.

Przyglądając się powyższemu komentarzowi, można w nim znaleźć kilka zagadnień, które Kościół w Polsce ma obowiązek podejmować w swoim nauczaniu w kontekście migracji i uchodźstwa:

a) Wszyscy ludzie są dziećmi Boga Stwórcy niezależnie od wyznania, w tym także muzułmanie. Jezus w tekście Ewangelii Mateusza utożsamia się ogólnie z ludźmi w potrzebie, a nie tymi, którzy Go „uznali za swojego Pana".

b) Papież nie chce „za wszelką cenę islamizować Europy”, tylko czynić ją bardziej chrześcijańską, bo nie jest chrześcijaninem ten, kto zamyka się na potrzeby drugiego człowieka.

c) Jeśli autorowi komentarza zależy na tym, by nie następowała „zamiana katolicyzmu na islam", ale odwrotnie, to można to zrobić miłością, tak jak to czynili pierwsi uczniowie Chrystusa, a nie nienawiścią. Chrześcijanie w Europie zdają trudny egzamin z wierności Chrystusowi, którego nauka dotycząca miłości bliźniego nigdy nie była łatwa.

d) Co do obaw dotyczących, ,gwałtów i nieludzkich morderstw przez ucinanie głów", to w interesie wszystkich ludzi na świecie jest współpraca

${ }^{36}$ Religia. Deon.pl. http://www.deon.pl/religia/kosciol-i-swiat/z-zycia-kosciola/art,25835, fran ciszek-do-centrum-astalli-uchodzcy-sa-darem.html [dostęp: 30.04.2016]. 
w walce $\mathrm{z}$ tymi, którzy to robią. Muzułmanie są na taką współpracę podobnie otwarci, jak i chrześcijanie.

Jeśli lęk przed atakami terrorystycznymi jest zrozumiały, to tego samego nie da się powiedzieć w przypadku utożsamiania islamu z terroryzmem. Przed laty ks. prof. Waldemar Chrostowski pisał, że: „,...] bardzo często dochodzi do zacierania różnic między tym, co ma charakter religijny, a tym, co religią nie jest. Wśród chrześcijan jest utrwalany stereotyp Araba i wyznawcy islamu - muzułmanina, jako terrorysty, osobnika, który bez skrupułów odwołuje się

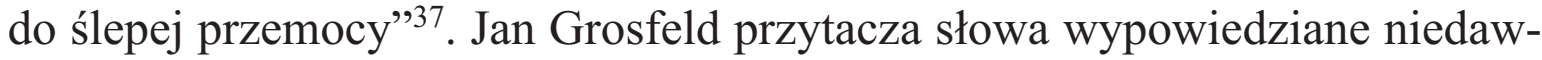
no przez pewnego dominikanina ze słynnej francuskiej Szkoły Biblijnej w Jerozolimie: „Obecnie największym wyzwaniem dla Kościoła jest lęk przed islamem”. Lęk ten jest sprzeczny z zasadami naszej wiary i powoduje tworzenie postaw sprzecznych $\mathrm{z}$ chrześcijaństwem ${ }^{38}$. Na lęk przed islamem ze względu na pojawiające się często ataki terrorystyczne można spojrzeć przez pryzmat nieakceptowanej ani przez prawo, ani przez teologię moralną zasadę odpowiedzialności zbiorowej. Mamy na pewno do czynienia z przypadkami radykalizacji muzułmanów w Europie i brania przez nich udziału w zamachach terrorystycznych inspirowanych przez ISIS. Niemniej jednak niedopuszczalne jest oskarżanie o to wspólnoty ludzi, tylko dlatego że wyznaje islam ${ }^{39}$.

W refleksji nad zjawiskiem lęków dotyczących tzw. zagrożenia kulturowego ze strony imigrantów z krajów muzułmańskich można przytoczyć opinię ks. Stanisława Olejnika: „Chrześcijańska miłość ojczyzny daleka jest od wrogiej czy pogardliwej postawy wobec innych narodów, ras czy kultur, a także wobec mniejszości narodowych, rasowych czy kulturowych zamieszkujących kraj ojczysty" 40 .

Celem powyższego artykułu było przedstawienie w skrócie ważniejszych zagadnień związanych ze współczesnym kryzysem migracyjnym w Europie w kontekście debaty na temat przyjmowania imigrantów i uchodźców oraz związanych z tym obaw. Początek artykułu zwracał uwagę na przyczyny mi-

${ }^{37}$ M. Rutkowska, Rozmowa z ks. prof. Waldemarem Chrostowskim, wykladowca Uniwersytetu Kardynała Stefana Wyszyńskiego w Warszawie i Uniwersytetu Mikołaja Kopernika w Toruniu, „Nasz Dziennik”, 20.12.2006.

38 J. Grosfeld, Lęk przed islamem, w: Kryzys migracyjny w Europie, dz. cyt., s. 100-101.

39 J. Balicki, Radykalizacja muzulmanów w Europie - przypadek Wielkiej Brytanii, w: Kryzys migracyjny w Europie, dz. cyt., s. 115-134.

40 S. Olejnik, Teologia moralna życia społecznego, Włocławek 2000, s. 371. 
gracji, które kiedyś powodowały wyjazdy mieszkańców Europy „za chlebem”. Podobne procesy związane z przejściem demograficznym zachodzą teraz w krajach Azji i Afryki i będą one długotrwałe. Obecny kryzys migracyjny najprawdopodobniej będzie się nasilał i będzie stanowił wyzwanie nie tylko dla naszego pokolenia. Jego ubocznym następstwem jest wzrost poparcia dla skrajnych polityków i ugrupowań, które zamiast jednoczyć, dążą do rozsadzenia od wewnątrz wspólnej Europy, której budowa została podjęta w celu uniknięcia tragedii podobnych do I i II wojny światowej. Wspólna Europa nie zdała egzaminu z solidarności wobec napływu w latach 2015 i 2016 niezwykle dużej liczby imigrantów i uchodźców. Będzie to miało na pewno sięgające w przyszłość konsekwencje, dotyczące nie tylko migracji. Brak solidarności w tej sprawie państw tworzących Wspólnotę jest jednym z wyzwań dla Kościoła.

Następnym wyzwaniem, które kryzys migracyjny stawia przed Kościołem, jest stosunek do osób starających się dotrzeć do Europy z rejonów biednych czy objętych konfliktami. Istnieje bogata w treści nauka społeczna Kościoła na temat nierówności społecznych, którą papież Franciszek adaptuje do aktualnej sytuacji.

Zadaniem Kościoła jest formowanie sumień. Kościołowi nie wolno milczeć. Będzie on wcześniej czy później oceniany z egzaminu, który mu przyszło zdawać w sytuacji kryzysu migracyjnego. Papież Franciszek niestrudzenie stara się budować pozytywne nastawienie do przybyszów, podejmując często pogłębioną refleksję na ten temat. Jego stanowisko jest niepopularne, o czym świadczy milczenie wielu ludzi, którzy z racji piastowania ważnych urzędów i przyznawania się do chrześcijaństwa, powinni zabierać głos w tej sprawie.

Wreszcie zagadnieniem, którym Kościół musi się zająć, jest podejście do muzułmanów. Jak wynika z przytoczonych badań, stosunek Soboru Watykańskiego II do islamu nie jest znany ani nie jest brany pod uwagę. Poza tym można wyciągnąć smutny wniosek, że osoby żywiące obawy o islamizację Europy przez imigrantów z krajów arabskich straciły wiarę w moc chrześcijaństwa. Chrześcijaństwo nie musi się obawiać konfrontacji z islamem. Może być ono bardzo atrakcyjne dla imigrantów z krajów muzułmańskich.

O ile prezentowane lęki przed islamizacją można interpretować jako słabość chrześcijan, to należy pamiętać, że obowiązujące w islamie Apostasy law, które zabrania pod karą śmierci zmiany religii, może być interpretowane jako wyraz jej słabości. W Iranie istnieje zakaz odprawiania Mszy Świętej w języku perskim przy otwartych drzwiach kościoła. Świadczy to o obawach przywódców islamu przed konwersjami Irańczyków na chrześcijaństwo. W każdym razie można śmiało sformułować tezę, że postawy części Europejczyków wobec imigrantów i uchodźców, szczególnie ze zniszczonej Syrii, nie budują pozytywnego obrazu chrześcijaństwa i pewnie nie sprzyjają ewangelizacji. 
Postawa przeciętnego muzułmanina wobec aktów terrorystycznych czy działań tzw. Państwa Islamskiego nie różni się zwykle od postawy przeciętnego chrześcijanina. Prawdą jest, że do Europy razem z imigrantami czy uchodźcami mogą docierać bojownicy tej organizacji. Jednak zadaniem służb jest ograniczenie czy wyeliminowanie tego typu przypadków. Na lotniskach $\mathrm{w}$ Londynie pracują $\mathrm{w}$ odpowiednich służbach muzułmanie, którym pewnie łatwiej rozpoznać potencjalnych terrorystów. W każdym razie niebezpieczeństwo to na pewno nie usprawiedliwia władz blokujących przyjazdy uchodźców ratujących swoje życie z miejsc konfliktów, uniemożliwiając organizacjom charytatywnym (także kościelnym) sprowadzania w ramach tzw. korytarzy humanitarnych osób wymagających leczenia, w większości starszych, kobiet i dzieci.

Jako podsumowanie powyższych rozważań warto przytoczyć słowa papieża skierowane do uchodźców 19 kwietnia 2016 roku w Rzymie:

[...] Wasze doświadczenie bólu i nadziei przypomina nam, że wszyscy jesteśmy cudzoziemcami i pielgrzymami na tej ziemi, przyjętymi przez kogoś ze szczodrością i nie dlatego, że na to zasługujemy. Każdy, kto tak jak wy uciekł z ojczystych stron z powodu ucisku, wojny, przyrody wyniszczonej zanieczyszczeniami i pustynnieniem czy też niesprawiedliwego podziału zasobów planety, jest bratem, z którym mamy dzielić chleb, dom, życie. Zbyt często was nie przyjęliśmy! Wybaczcie zamknięcie i obojętność naszych społeczeństw, które obawiają się zmiany życia i mentalności, jakiej domaga się wasza obecność. Traktowani jako ciężar, jako problem, jako coś, co kosztuje, w istocie jesteście darem [...] każdy z was może być mostem łączącym odległe ludy, który sprawia, że spotkania różnych kultur i religii są możliwe, drogą do ponownego odkrycia naszego wspólnego człowieczeństwa ${ }^{41}$.

\section{CONTEMPORARY MIGRATION CRISIS. CHALLENGES FOR THE CHURCH}

\section{Summary}

The aim of this article is to draw attention to the challenges facing the Church in the current migration crisis in Europe, in the context of the debate on the admission of illegal immigrants and refugees arriving in Europe and the related social and cul-

${ }^{41}$ Franciszek do Centrum Astalli: uchodźcy nie sa problemem, sq darem, http://pl.radiovaticana. va/news/2016/04/19/franciszek_do_centrum_astalli_uchod\%C5\%BAcy_nie_s\%C4\%85_pro blemem/1223985 [dostęp: 30.04.2016]. 
tural security.The article consists of three parts. The first is the historical dimension of migration and exile in Europe and the world. The second part presents the attitude of European societies to immigrants and refugees. Part three deals with current migration and refugee challenges for the Church.

Conclusions: In the debate on the contemporary influx of immigrants to Europe, we cannot forget the mass emigration from Europe in the nineteenth century, the first half of the $20^{\text {th }}$ century, and refugees connected with the First and Second World Wars. Catholic Church in Poland should address firstly the lack of solidarity found between the EU states in addressing the problems of the migration crisis; secondly the attitude of Christians, which is not always in line with the teachings of the second Vatican Council, towards Muslims who seek to reach Europe from poor or conflicted regions.

Słowa kluczowe: migracje; uchodźstwo; mniejszości kulturowe; muzułmanie; islam; islamofobia; ataki terrorystyczne; chrześcijaństwo; Sobór Watykański II; relacje chrześcijańsko-muzułmańskie

Keywords: migration; refugee; cultural minorities; Muslims; Islam; Islamophobia; Terrorist attacks; Christianity; Second Vatican Council; Christian-Muslim relations

\section{BIBLIOGRAFIA}

244 million international migrants living abroad worldwide, new UN statistics revealed, http:// www.un.org/sustainabledevelopment/blog/2016/01/244-million-international-migrants-livingabroad-worldwide-new-un-statistics-reveal/ [dostęp: 30.04.2016].

5 facts about the Muslim population in Europe, Pew Research Center, 19.07.2016, http://www. pewresearch.org/fact-tank/2016/07/19/5-facts-about-the-muslim-population-in-europe [dostęp: 30.07.2016].

Badanie na temat postaw wobec cudzoziemców w Polsce, Ipsos dla IOM, Warszawa, wrzesień 2016, http://poland.iom.int/sites/default/files/IOM_Cudzoziemcy_raport_IX_2016.pdf_[dostęp: 30.10.2016].

Balicki J., Frątczak E., Nam Ch.B., Przemiany ludnościowe. Fakty - interpretacje - opinie. Mechanizmy przemian ludnościowych. Globalna polityka ludnościowa, Instytut Politologii UKSW, Wydawnictwo UKSW, Warszawa 2007.

Balicki J., Christian-Muslim co-operation in a secular age. Area of collaboration, „Chrześcijaństwo. Świat-Polityka”, „Zeszyty Społecznej Myśli Kościoła” nr 20 (2016), s. 41-58.

Balicki J., „Dzieci Abrahama”. Chrześcijaństwo - islam w dobie kryzysu migracyjnego, „Civitas. Studia z Filozofii Polityki”, nr 19: Gościnność, 2016, s. 111-137.

Balicki J., Przestanki demograficzne islamofobii w Zachodniej Europie. Analiza krytyczna, „Roczniki Nauk Społecznych" t. 6, nr 3, 2014, s. 11-30.

Balicki J., Radykalizacja muzulmanów w Europie - przypadek Wielkiej Brytanii, w: Kryzys migracyjny w Europie. Wyzwania etyczne, spoleczno-kulturowe i etniczne, red. J. Balicki, W. Necel, Wydawnictwo UKSW, Warszawa 2017, s. 115-134. 
Balicki J., Sekularyzacja Europy - szansa czy wyzwania dla integracji imigrantów z krajów muzutmańskich? Przypadek Wielkiej Brytanii, „Colloquium Wydziału Nauk Humanistycznych i Społecznych. Kwartalnik" 4 (2015), s. 7-26.

Balicki J., Stalker P., Polityka imigracyjna i azylowa. Wyzwania i dylematy, wyd. UKSW, Warszawa 2006.

Balicki J., Unia Europejska jako podmiot polityki wobec uchodźców, w: Uchodźcy w Europie. Uwarunkowania. Istota. Następstwa, red. A. Wojtaszczyk, J. Szymańska, Instytut Europeistyki. Wydział Nauk Politycznych i Studiów Międzynarodowych UW, Warszawa 2016, s. 110-124.

Balicki J., Wells A., Attitudes Towards Muslims and Hindus in England. Are British People Afraid of Muslims?, „Studia Gdańskie” 29 (2016), s. 219-294.

Chrześcijański ksztalt patriotyzmu. Dokument Konferencji Episkopatu Polski przygotowany przez Radę ds. Społecznych, 27.04.2017, http://episkopat.pl/chrzescijanski-ksztalt-patriotyzmudokument-konferencji-episkopatu-polski-przygotowany-przez-rade-ds-spolecznych/ [dostęp: 30.04.2017].

Cieślikowska D., Jak rozmawiać o uchodźcach - komentarz do scenariuszy lekcji, w: Rozmowy o uchodźcach, Centrum Edukacji Obywatelskiej. Centrum edukacji o uchodźcach, https://migracje.ceo.org.pl/materialy-metodyczne/_[dostęp: 30.05.2017].

Franciszek do Centrum Astalli: uchodźcy nie sa problemem, sq darem, http://pl.radiovaticana.va/ news/2016/04/19/franciszek_do_centrum_astalli_uchod\%C5\%BAcy_nie_s\%C4\%85_problemem/1223985/ [dostęp: 30.04.2016].

Grosfeld J., Lęk przed islamem, w: Kryzys migracyjny w Europie. Wyzwania etyczne, spoleczno-kulturowe i etniczne, red. J. Balicki, W. Necel, Wydawnictwo UKSW, Warszawa 2017, s. 98-113.

Jonda B., Muzulmańscy imigranci i uchodźcy ,papierkiem lakmusowym” dla niemieckiego społeczeństwa?, w: Kryzys migracyjny w Europie. Wyzwania etyczne, społeczno-kulturowe i etniczne, red. J. Balicki, W. Necel, Wydawnictwo UKSW, Warszawa 2017, s. 175-206.

Loredo J., Imigracja czy inwazja? „Nasz Dziennik” 24 października 2016 (przedruk z włoskiego miesięcznika „Radici Cristiane”, tłum. P. Jaroszyński, http://www.naszdziennik.pl/mysl/168935,imigracja-czy-inwazja.html/ [dostęp: 30.10.2016].

Łodziński S., Migracyjna „panika moralna”? Polska opinia publiczna wobec udzielania pomocy uchodźcom w okresie maj - grudzień 2015 r., w: Kryzys migracyjny w Europie. Wyzwania etyczne, spoleczno-kulturowe i etniczne, red. J. Balicki, W. Necel, Wydawnictwo UKSW, Warszawa 2017, s. 155-174.

Mixed Migration Flows in the Mediterranean and Beyond. Refugees and migrants face heightened risks while trying to reach Europe - UNHCR Report, 27 February 2017, http://www.unhcr.org/ news/press/2017/2/58b458654/refugees-migrants-face-heightened-risks-trying-reach-europeunhcr-report.html/ [dostęp: 30.03.2016].

Necel W., Duszpasterz ludzi w drodze wobec procesu integracji kościelnej imigrantów, w: J. Balicki, M. Chamarczuk, Wokót problematyki migracyjnej. Kultura przyjęcia, Rządowa Rada Ludnościowa, Międzyinstytutowy Zakład Badań nad Migracją UKSW, Wydawca: Ministerstwo Rozwoju Regionalnego, Warszawa 2013, s. 275-287.

Necel W., Kultura przyjęcia wobec imigrantów wg instrukcji Erga migrantes caritas Christi, w: Kryzys migracyjny w Europie. Wyzwania etyczne, spoleczno-kulturowe i etniczne, red. J. Balicki, W. Necel, Wydawnictwo UKSW, Warszawa 2017, s. 83-97.

Olejnik S., Teologia moralna fundamentalna, WWD, Włocławek 1998.

Olejnik S., Teologia moralna życia społecznego, WWD, Włocławek 2000.

Orędzie Franciszka na Światowy Dzień migranta i uchodźcy 2016, „, Migranci i uchodźcy sa dla nas wyzwaniem. Odpowiedź daje Ewangelia miłosierdzia”, 17 stycznia 2016, https://stacja7.pl/z-watykanu/oredzie-franciszka-na-swiatowy-dzien-migranta-i-uchodzcy [dostęp: 1.03.2016].

Religia. Deon.pl., http://www.deon.pl/religia/kosciol-i-swiat/z-zycia-kosciola/art,25835,franciszekdo-centrum-astalli-uchodzcy-sa-darem.html/ [dostęp: 30.04.2016]. 
Rutkowska M., Rozmowa z ks. prof. Waldemarem Chrostowskim, wyktadowca Uniwersytetu Kardynała Stefana Wyszyńskiego w Warszawie i Uniwersytetu Mikołaja Kopernika w Toruniu, „Nasz Dziennik", 20.12.2006.

Sobór Watykański II, Deklaracja o stosunku Kościoła do religii niechrześcijańskich Nostra aetate, w: Sobór Watykański II. Konstytucje. Dekrety. Deklaracje, Wyd. Pallottinum, Poznań 1968, s. 334-338.

Stola D., Wielkie migracje w Europie XX wieku, w: Cywilizacja europejska. Eseje i szkice z dziejów cywilizacji i dyplomacji, red. M. Koźmiński, Instytut Historii PAN, Warszawa 2010, s. 355-375.

Walaszek A., Migracje Europejczyków 1650-1914, Wydawnictwo UJ, Kraków 2007.

Wojtalik M., Ilu muzutmanów mieszka w Polsce? Polacy bardzo się myla, Newsweek.pl, 14.12.2016, http://www.newsweek.pl/polska/ilu-muzulmanow-mieszka-w-polsce-dane-i-wyniki-badan,ar tykuly,402066,1.html/ [dostęp: 15.12.2016].

Wyznania religijne w Polsce, GUS, Warszawa 2016.

JANUSz BALICKI - pracownik naukowo-dydaktyczny Instytutu Politologii Uniwersytetu Kardynała Stefana Wyszyńskiego w Warszawie, dr hab. prof. UKSW, kierownik Katedry Polityk Publicznych, kierownik Międzyinstytutowego Zakładu Badań nad Migracją, wykładowca Gdańskiego Seminarium Duchownego, członek Komitetu Badań nad Migracjami PAN oraz Rządowej Rady Ludnościowej. Obszar badań: demografia społeczna, polityka ludnościowa, polityka imigracyjna i azylowa UE, integracja imigrantów z różnych kultur, szczególnie z krajów muzułmańskich, humanizacja polityki imigracyjnej i azylowej UE. 